\title{
Induction of MMP-9 release from human dermal fibroblasts by thrombin: involvement of JAK/STAT3 signaling pathway in MMP-9 release
}

\author{
Li Wang1, Jianmin $\mathrm{Luo}^{3}$ and Shaoheng $\mathrm{He}^{* 1,2}$
}

Address: ${ }^{1}$ The First Affiliated Hospital, Shantou University Medical College, Shantou 515041, China, ${ }^{2}$ Clinical Experiment Center, the First Affiliated Hospital of Nanjing Medical University, Nanjing, Jiangsu 210029, China and ${ }^{3}$ The Laboratory for Neural Repair, Shantou University Medical College, Shantou 515041, China

Email: Li Wang - pfkwangli@163.com; Jianmin Luo - jml@stu.edu.cn; Shaoheng He* - Shoahenghe@hotmail.com

* Corresponding author

Published: 7 May 2007

BMC Cell Biology 2007, 8:14 doi:10.1 186/147I-2121-8-14

This article is available from: http://www.biomedcentral.com/|47|-2/2I/8/14

(c) 2007 Wang et al; licensee BioMed Central Ltd.

This is an Open Access article distributed under the terms of the Creative Commons Attribution License (http://creativecommons.org/licenses/by/2.0), which permits unrestricted use, distribution, and reproduction in any medium, provided the original work is properly cited.
Received: 30 July 2006

Accepted: 7 May 2007

\begin{abstract}
Background: It has been recognized that dermal fibroblasts and matrix metalloproteases (MMP) play crucial roles in wound healing process in skin. Thrombin was found to stimulate IL-8 release from human dermal fibroblasts (HDFs). However, little is known of the effect of thrombin on secretion of MMPs from dermal fibroblasts. In the present study, the influence of thrombin on proMMP-2 and proMMP-9 activity release from primary cultured HDFs, and its potential signaling pathways were investigated.
\end{abstract}

Results: The results showed that thrombin induced proMMP-9, but not proMMP-2 release from HDFs in a dose dependent manner at $6 \mathrm{~h}$ following incubation. Thrombin also upregulated expression of proMMP-9 mRNA in HDFs. Hirudin completely abolished the action of thrombin on HDFs. An agonist peptide of protease-activated receptor-I, SFLLR-NH $\mathrm{N}_{2}$ stimulated an enhanced release of proMMP-9 from HDFs. AG490, an inhibitor of STAT3 inhibited basal and thrombinprovoked proMMP-9 release and phosphorylation of STAT3. PD98059, an inhibitor of MAPK and LY294002, an inhibitor PI3K failed to significantly inhibit thrombin induced proMMP-9 release.

Conclusion: Thrombin is a potent stimulus of proMMP-9 release from HDFs. Thrombin induced proMMP-9 release is most likely through activation of PAR-I. JAK/STAT3 signaling pathway is involved in proMMP-9 release from HDFs.

\section{Background}

The MMPs, also called matrixin, play a key role in the processes of embryonic development, morphogenesis, reproduction, tissue remodeling and tumor invasion and metastasis [1]. MMP-2 and MMP-9 are geletinases, which degrade type IV collagen, a major constituent of basement membranes, denatured interstitial collagens (gelatins), laminin, elastin, and fibronectin [2]. They are secreted as zymogens with a molecular weight of proMMP-2 being 72 $\mathrm{kDa}$ and proMMP-9 being $97 \mathrm{kDa}$. Dermal fibroblasts produce and organize the extracellular matrix of the dermis. They are able to generate MMPs including MMP-2 and MMP-9, collagen, other extracellular matrix components and cytokines upon activation [3]. 
In recent years, thrombin has been discovered to play important roles in inflammatory and tissue repair processes by influencing vascular and blood cells including endothelial cells [4], fibroblasts [5], vascular smooth muscle cells [6], T lymphocytes [7], eosinophils [8] and monocytes [9]. As a serine protease, thrombin exerts many of its actions through proteolytic activation of its receptors including protease-activated receptor (PAR)-1, PAR-3 and PAR-4 [10]. These receptors can also be activated without proteolytic cleavage using five to six residue peptides corresponding to the new $\mathrm{N}$ termini of the cleaved receptors [11]. PARs are 'single-use' receptors: proteolytic activation is irreversible and the cleaved receptors are degraded in lysosomes. Thus, PARs play important roles in 'emergency situations', such as trauma and inflammation, although their other potential downstream signaling targets have not been fully established [12].

Recently, it was demonstrated that human dermal fibroblasts express PAR-1 and PAR-3, and thrombin is able to stimulate IL- 8 release from these fibroblasts predominantly through MAPK/ERK and p38 MAPK signaling pathways [13]. However, little is known of influence of thrombin on MMP-9 and MMP-2 release from fibroblasts. We therefore investigate the action of thrombin on MMP9 and MMP-2 release from primary HDFs and its potential intracellular signaling pathways in the present study.

\section{Results}

\section{Expression of PARs in HDFs}

Immunofluorescence staining showed that primary cultured HDFs expressed proteins of PAR-1, PAR-2, PAR-3, but not PAR-4 (Fig. 1). An agarose gel electrophoresis revealed that primary cultured HDFs expressed PAR-1, PAR-2, PAR-3, but not PAR-4 mRNAs (Fig. 2).

\section{Influence of thrombin on proMMP-2 and proMMP-9 secretion from HDFs}

Thrombin at the concentrations of $0.1,1$ and $5 \mathrm{U} / \mathrm{ml}$ provoked a concentration-dependent increase in proMMP-9 activity from primary cultured HDFs following $6 \mathrm{~h}$ incubation. As little as $1 \mathrm{U} / \mathrm{ml}$ of thrombin was able to induce significant increase in release of proMMP-9 activity from HDFs (Fig. 3A). The upregulated expression of MMP-9 mRNA in HDFs was found when HDFs were incubated with thrombin at 1 and $5 \mathrm{U} / \mathrm{ml}$ for $6 \mathrm{~h}$ (Fig. 3C). In contrast, thrombin at the concentrations tested had no siginificant effect either on secretion of proMMP-2 activity (Fig. $3 \mathrm{~A}$ ) or on expression MMP-2 mRNA (data not shown) following $6 \mathrm{~h}$ incubation period. Hirudin, a specific thrombin inhibitor at the concentrations of 1 and $5 \mathrm{U} / \mathrm{ml}$ completely abolished thrombin-induced release of proMMP-9 activity after $6 \mathrm{~h}$ incubation (Fig. 3B).
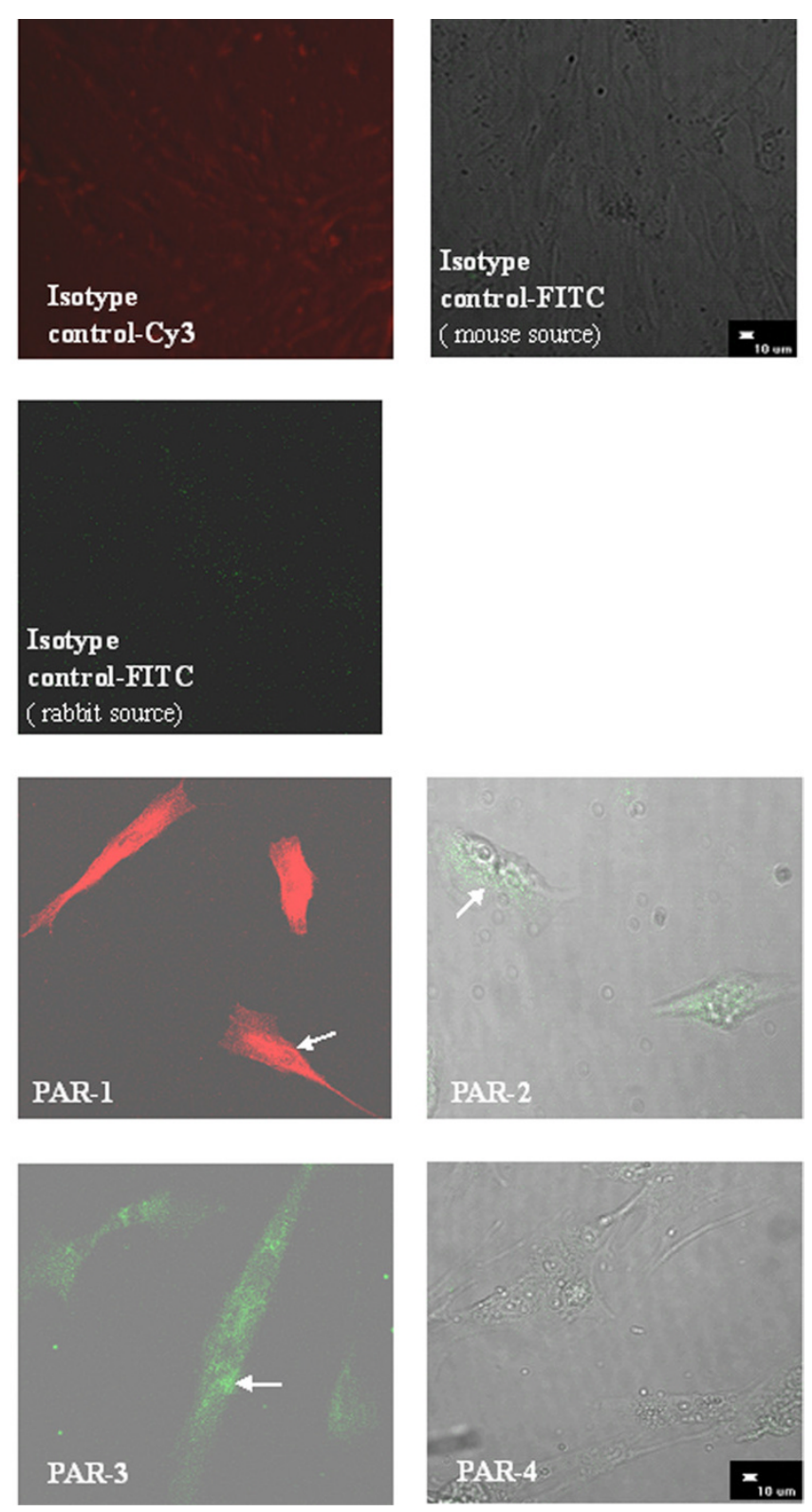

\section{Figure I}

Determination of expression of PAR proteins in HDFs by immunofluorescence staining. HDFs appear to express PARI, PAR-2, PAR-3, but not PAR-4 proteins.

SFLLR-NH $\mathrm{H}_{2}$, a PAR-1 agonist peptide at the concentration of $100 \mu \mathrm{M}$ induced a significant release of proMMP-9 activity at $6 \mathrm{~h}$ following incubation (Fig. 4A). It appeared that SFLLR-NH $\mathrm{NH}_{2}$ at $100 \mu \mathrm{M}$ was able to also elicit enhanced secretion of proMMP-2 activity from HDFs though this did not reach statistical significance level (Fig. $4 \mathrm{~A})$. As a positive control, TGF $\beta$ at $10 \mathrm{ng} / \mathrm{ml}$ induced significant release of proMMP-9 activity from HDFs (Fig. 4A). RLLFS-NH $\mathrm{N}_{2}$, a reverse peptide of SFLLR-NH $\mathrm{N}_{2}$ had little effect on release of proMMP-9 and proMMP-2 activities 


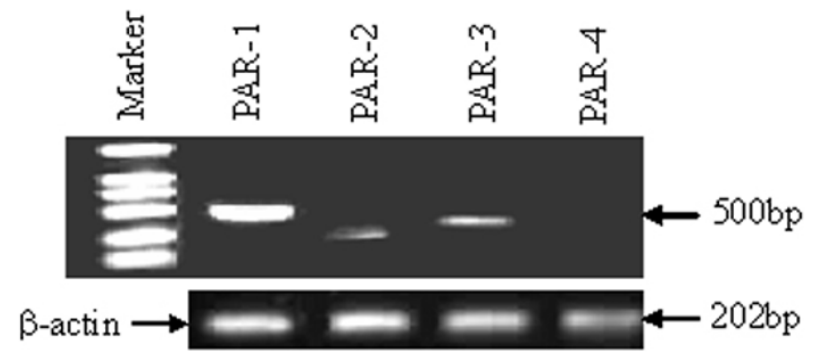

Figure 2

Determination of expression of PAR mRNAs in HDFs by RTPCR. HDFs express PAR-I, PAR-2, PAR-3, but not PAR-4 mRNAs.

from HDFs (Fig. 4B). A PAR-1 blocking antibody completely blocked SFLLR-NH $\mathrm{H}_{2}$ induced release of proMMP-9 activity (Fig. 4B).

\section{Effect of PD98059, LY294002 and AG490 on thrombin-} induced release of proMMP-9 activity

Following $2 \mathrm{~h}$ and $6 \mathrm{~h}$ incubation periods, AG490, a JAK/ STAT3 pathway inhibitor reduced significantly basal and thrombin-provoked release of proMMP-9 activity (Fig. 5A) and expression of proMMP-9 mRNA in HDFs (Fig. 5B). It was observed also that PD98059, an inhibitor of MAPK pathway and LY294002, an inhibitor of PI3K were able to inhibit thrombin-provoked release of proMMP-9 activity from HDFs though the inhibition does not reach statistical significance level (Fig. 5A). AG490, PD98059 and LY294002 have little influence on basal or thrombininduced release of proMMP-2 activity from HDFs following both $2 \mathrm{~h}$ and $6 \mathrm{~h}$ incubation periods (Fig. 5A).

\section{Effect of AG490 on STAT3 phosphorylation in HDFs}

Thrombin at a concentration of $5 \mathrm{U} / \mathrm{ml}$ enhanced phosphorylation of STAT3 in HDFs following $30 \mathrm{~min}, 2 \mathrm{~h}$ and $6 \mathrm{~h}$ incubation periods. The action of thrombin on JAK/ STAT3 pathway was completely abolished by AG490. AG490 also significantly reduced basal phosphorylation of STAT3 in HDFs following $30 \mathrm{~min}, 2 \mathrm{~h}$ and $6 \mathrm{~h}$ incubation periods (Fig. 6).

\section{Effect of PD98059 on ERK I/2 phosphorylation in HDFs}

Thrombin at a concentration of $5 \mathrm{U} / \mathrm{ml}$ induced an enhanced phosphorylation of ERK1/2 in HDFs following $2 \mathrm{~h}$ and $6 \mathrm{~h}$ incubation periods. PD98059 was able to completely block thrombin induced phosphorylation of ERK1/2 when it was incubated with HDFs for $2 \mathrm{~h}$ and $6 \mathrm{~h}$. PD98059 inhibited also basal phosphorylation of ERK1/ 2 in HDFs following $2 \mathrm{~h}$ and $6 \mathrm{~h}$ incubation periods (Fig. 7)
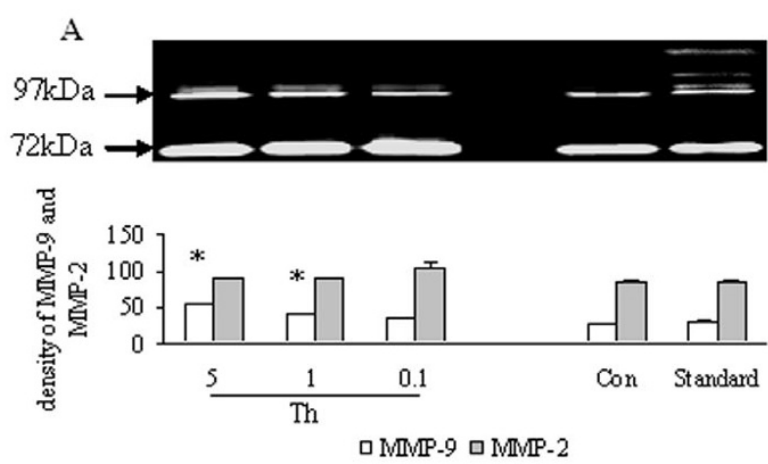

B
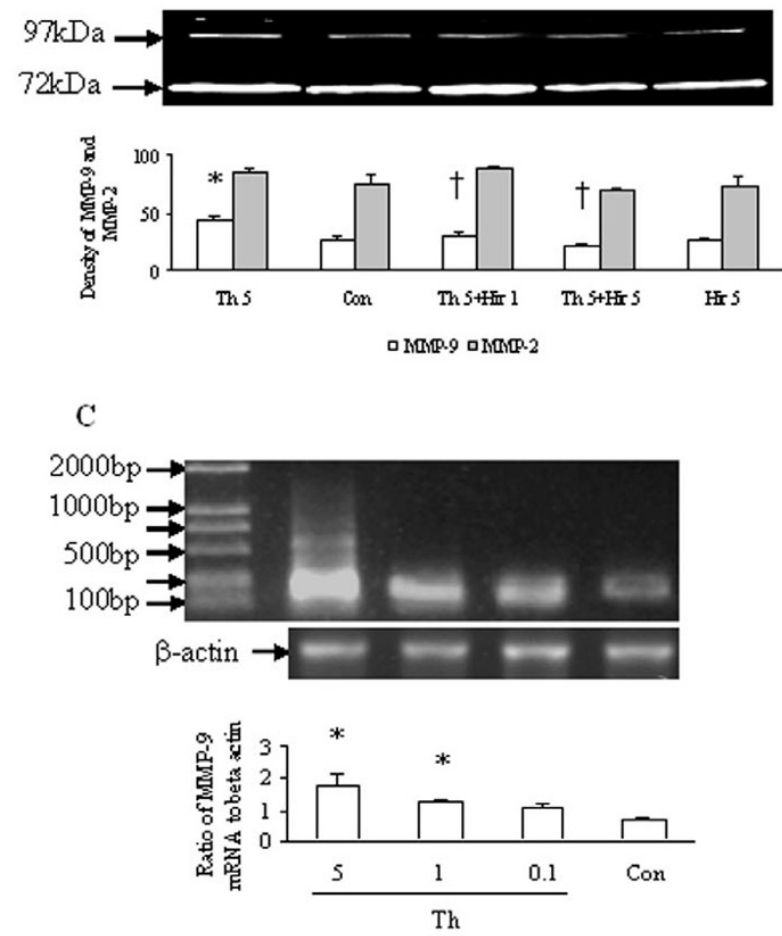

Figure 3

Effects of thrombin (Th, $\mathrm{U} / \mathrm{ml})$, hirudin $(\mathrm{Hir}, \mathrm{U} / \mathrm{ml}$ ) on release of MMP-2 and MMP-9 activities, and influence of Th on expression of MMP-9 mRNA in HDFs. The cells were incubated with Th, Hir at $37^{\circ} \mathrm{C}$ for 6 h. Gelatin zymography was used to detect proMMP-2 and proMMP-9 activities. (A) MMP-2 and MMP-9 activities released from HDFs in response to various concentrations of Th; (B) MMP-2 and MMP-9 activities released from HDFs in response to Th at 5 $\mathrm{U} / \mathrm{ml}$ and Hir; (C) MMP-9 mRNA expression in HDFs in response to various concentrations of Th. The values shown are Mean \pm SD for four separate experiments. Cells from each one of the four dermal fibroblast donors were used for one independent experiment. $* \mathrm{P}<0.05$ in comparison with the response to medium alone (Con); $\nmid P<0.05$ in comparison with the response to the corresponding stimulus alone. 
A
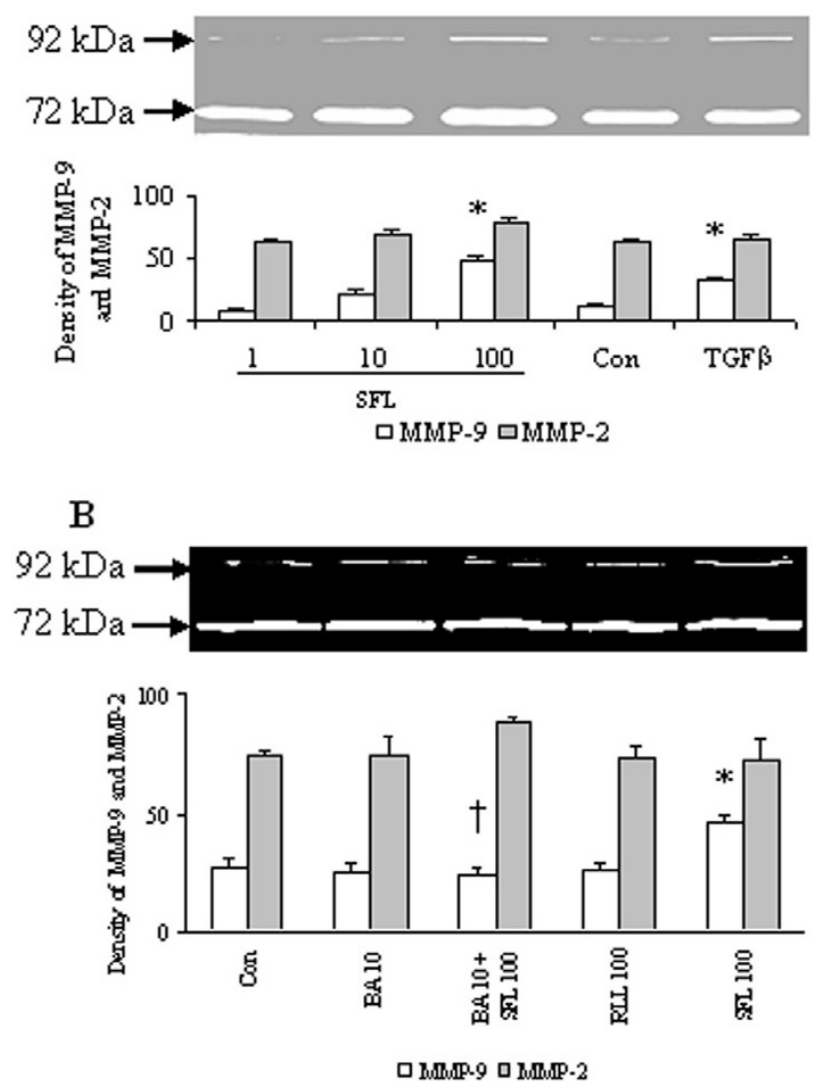

\section{Figure 4}

Effects of SFLLR-NH2 (SFL, $\mu M$ ) and RLLFS-NH2 (RLL, $\mu M)$ on release of MMP-2 and MMP-9 activities in HDFs. The cells were incubated with SFL, RLL or PAR-I blocking antibody $(B A, \mu g / m l)$ at $37^{\circ} \mathrm{C}$ for $6 \mathrm{~h}$, respectively. Gelatin zymography was used to detect proMMP-2 and proMMP-9 activities. (A) MMP-2 and MMP-9 activities released from HDFs in response to various concentrations of SFL and TGF $\beta$ at 10 $\mathrm{ng} / \mathrm{ml}$ (as a positive control); (B) MMP-2 and MMP-9 activities released from HDFs in response to SFL, RLL and BA. The values shown are Mean \pm SD for four separate experiments. Cells from each one of the four dermal fibroblast donors were used for one independent experiment. $* \mathrm{P}<0.05$ in comparison with the response to medium alone (Con); $\uparrow \mathrm{P}<$ 0.05 in comparison with the response to the corresponding stimulus alone.

\section{Effect of LY294002 on Akt phosphorylation in HDFs}

Thrombin at a concentration of $5 \mathrm{U} / \mathrm{ml}$ failed to induce significantly increased phosphorylation of Akt in HDFs. LY294002 diminished basal phosphorylation of Akt in HDFs at $2 \mathrm{~h}$, but not $6 \mathrm{~h}$ following incubation, but had little effect on the action of thrombin in HDFs (Fig. 8).

\section{Discussion}

It was found that thrombin was able to induce proMMP9 secretion from primary cultured HDFs, indicating that it
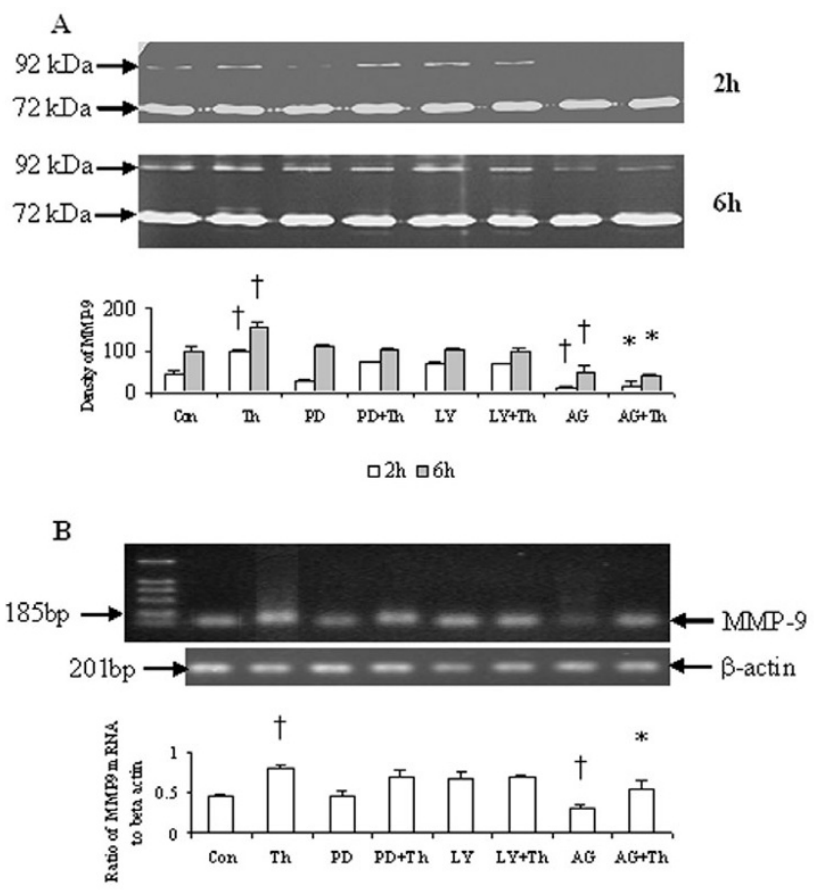

Figure 5

Effect of AG490 (AG), PD98059 (PD) and LY294002 (LY) on MMP-2 and MMP-9 activity release and MMP-9 mRNA expression in HDFs. (A) HDFs were incubated with AG490 $(40 \mu \mathrm{M})$, PD98059 $(50 \mu \mathrm{M})$ and LY294002 $(40 \mu \mathrm{M})$ in the presence or absence of thrombin (Th, $5 \mathrm{U} / \mathrm{ml}$ ) at $37^{\circ} \mathrm{C}$ for 2 $\mathrm{h}$ and $6 \mathrm{~h}$, and MMP-2 and MMP-9 activities were detected with zymograph. (B) HDFs were incubated with AG490, PD98059 and LY294002 in the presence or absence of Th at $37^{\circ} \mathrm{C}$ for $6 \mathrm{~h}$, and MMP-9 mRNA was detected by RT-PCR analysis. The relative levels of MMP-9 mRNA were expressed as the ratio to $\beta$-actin. The values shown are Mean \pm SD for four separate experiments. Cells from each one of the four dermal fibroblast donors were used for one independent experiment. $\dagger P<0.05$ compared with the response to medium alone (Con); $* \mathrm{P}<0.05$ compared with the response to thrombin alone.

is likely involved in the tissue remodeling process in the body. In the parallel experiment, thrombin failed to stimulate enhanced proMMP-2 activity release from HDFs, implicating that the action of thrombin on HDFs was a selective one. Selective release of MMP-9 from fibroblasts has been observed previously with rat mast cell sonicate $[14]$, which may support the above view. Since the proMMP-9 activity released from HDFs in response to thrombin at 1 and $5 \mathrm{U} / \mathrm{ml}$ and SFLLR- $\mathrm{NH}_{2}$ at $100 \mu \mathrm{M}$ was similar to the activity released in response to TGF $\beta$ at 10 $\mathrm{ng} / \mathrm{ml}$, it implicated that thrombin was a potent secretogogue of proMMP-9 activity release from HDFs.

It appeared that thrombin induced proMMP-9 release was most likely through activation of PAR-1 as HDFs express PAR-1, PAR-2 and PAR-3, PAR-2 is not a receptor for 
$30 \mathrm{~min}$

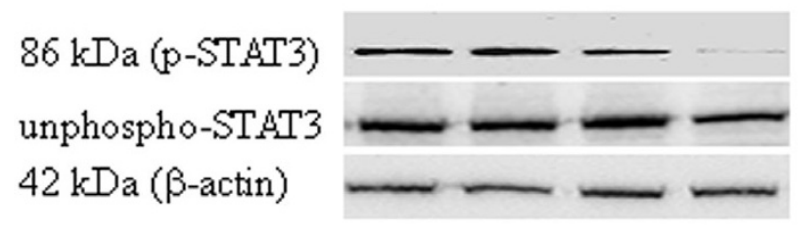

$2 h$

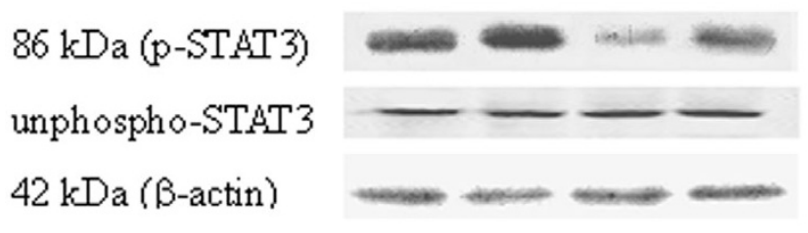

$6 \mathbf{h}$

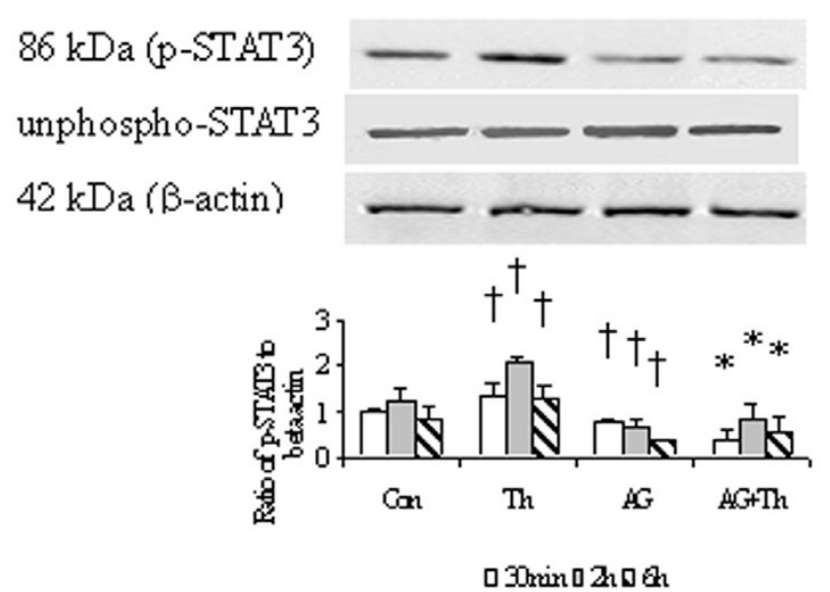

\section{Figure 6}

Western blot analysis of effect of AG490 (AG), a JAK/STAT pathway inhibitor on the phosphosrylation of STAT3 in HDFs. Cells were incubated with AG $(40 \mu \mathrm{M})$, thrombin (Th, $5 \mathrm{U} / \mathrm{ml}$ ) or $\mathrm{Th}+\mathrm{AG}$ at $37^{\circ} \mathrm{C}$ for $30 \mathrm{~min}, 2 \mathrm{~h}$ and $6 \mathrm{~h}$, respectively. Densitometry analysis of immunoblots was carried out using a Scion Image software. The relative levels of phosphoSTAT3 were expressed as the ratio to $\beta$-actin. The values shown are Mean \pm SD for four separate experiments. Cells from each one of the four dermal fibroblast donors were used for one independent experiment. $\dagger P<0.05$ compared with the response to medium alone (Con); * $\mathrm{P}<0.05 \mathrm{com}-$ pared with the response to thrombin alone.

thrombin and PAR-3 could not be activated by thrombin alone [15]. Our preliminary experiment revealed that a specific agonist peptide of PAR-3, TFRGAP- $\mathrm{NH}_{2}$ had little effect on proMMP-9 or proMMP-2 release from HDFs (data not shown). The observations that an agonist peptide of PAR-1, SFLLR-NH ${ }_{2}$, but not its reverse peptide was able to stimulate proMMP-9 release from HDFs, and that
$2 h$

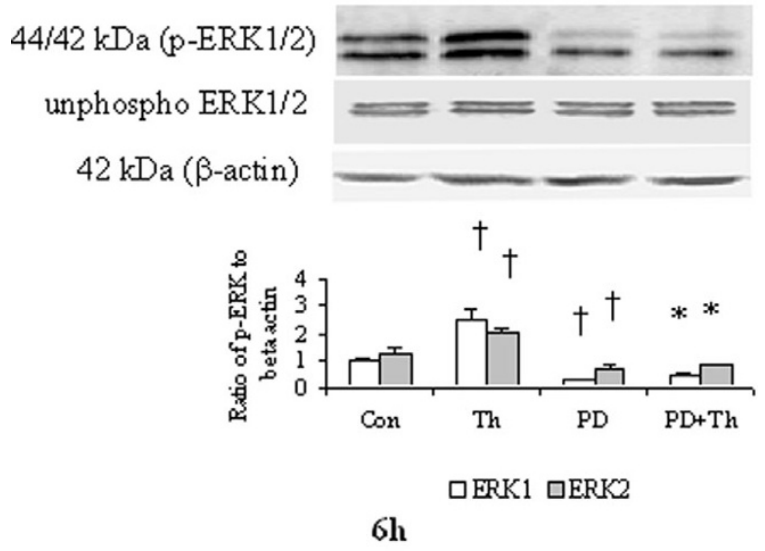

$44 / 42 \mathrm{kDa}(\mathrm{p}-\mathrm{ERK} 1 / 2)$

unphospho-ERK1/2

$42 \mathrm{kDa}(\beta-\mathrm{actin})$
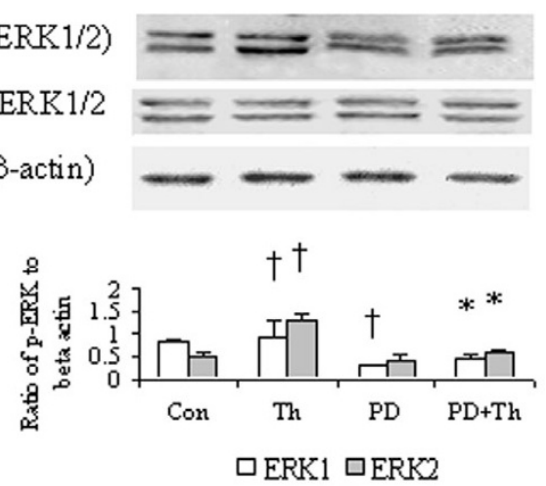

Figure 7

Western blot analysis of effect of PD98059 (PD), a MAPK pathway inhibitor on the phosphorylation of ERKI/2 in HDFs. Cells were incubated with PD $(50 \mu \mathrm{M})$, thrombin (Th, $5 \mathrm{U} / \mathrm{ml}$ ) or Th $+\mathrm{PD}$ at $37^{\circ} \mathrm{C}$ for $2 \mathrm{~h}$ or $6 \mathrm{~h}$, respectively. Densitometry analysis of immunoblots was carried out using a Scion Image software. The relative levels of phospho-ERKI/ 2 were expressed as the ratio to $\beta$-actin. The values shown are Mean \pm SD for four separate experiments. Cells from each one of the four dermal fibroblast donors were used for one independent experiment. $\dagger P<0.05$ compared with the response to medium alone (Con); $* \mathrm{P}<0.05$ compared with the response to thrombin alone.

PAR-1 blocking antibody completely blocked the action of SFLLR-NH $\mathrm{H}_{2}$ on HDFs comfirmed that activation of PAR1 was responsible for thrombin induced release of proMMP-9 from HDFs. The PAR-1 blocking antibody ATAP2 employed in the present study was reported previously as a cleavage-blocking anti-PAR-1 antibody, which abolished completely activated-protein-C induced activation of PAR-1 [16]. It has been reported before that activation of PAR-1 could cause release of IL-8 [13], monocyte chemotactic protein-1 [17] and IL-6 [18] from fibroblasts, which may further support our current finding that stimulation of proMMP-9 release from HDFs by thrombin is likely through activation of PAR-1. 


\section{$2 h$}

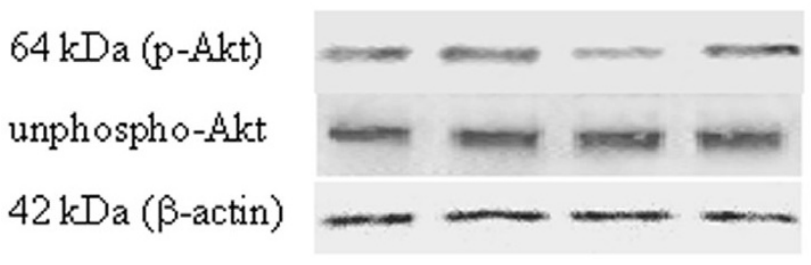

$6 \mathbf{h}$
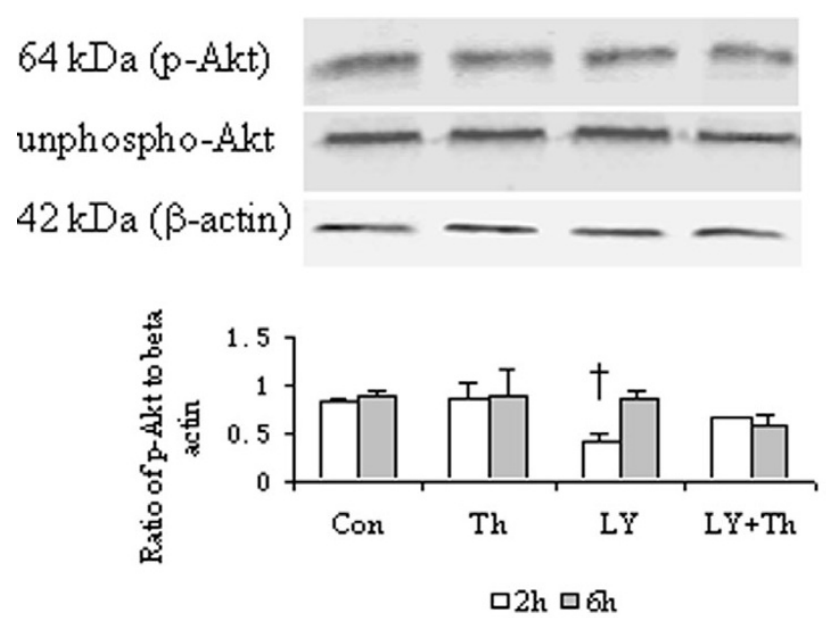

Figure 8

Western blot analysis of effect of LY294002 (LY), a PI3K pathway inhibitor on phosphorylation of Akt in HDFs. Cells were incubated with LY $(40 \mu \mathrm{M})$, thrombin $(\mathrm{Th}, 5 \mathrm{U} / \mathrm{ml})$ or $\mathrm{Th}+\mathrm{LY}$ at $37^{\circ} \mathrm{C}$ for $2 \mathrm{~h}$ or $6 \mathrm{~h}$, respectively. Densitometry analysis of immunoblots was carried out using a Scion Image software. The relative levels of phospho-Akt were expressed as the ratio to $\beta$-actin. The values shown are Mean \pm SD for four separate experiments. Cells from each one of the four dermal fibroblast donors were used for one independent experiment. $\dagger P<0.05$ compared with the response to medium alone (Con).

It seems likely that thrombin induced proMMP-9 release was associated with JAK/STAT3, but not MAPK/ERK and PI3K/Akt signaling pathways as inhibitors of STAT3 was able to inhibit thrombin induced proMMP-9 release. The observations that thrombin was capable of stimulating phosphorylation of STAT3, and that AG490 could inhibit thrombin provoked phosphorylation of STAT3 indicate further that thrombin induced proMMP-9 release is associated with JAK/STAT3 signaling pathway in HDFs. However, AG490 itself inhibited basal phosphorylation of STAT3, indicating phosphorylation of STAT3 occurred even when these cells were not under stimulation. Provoking phosphorylation of STAT3 by thrombin has been found with vascular smooth muscle cells previously [19].
Although PD98059, a specific inhibitor of MAPK pathway eliminated thrombin induced phosphorylation of ERK1/ 2 , it failed to significantly inhibit thrombin induced proMMP-9 release from HDFs, indicating MAPK/ERK signaling pathway is unlikely a major pathway for thrombin induced proMMP-9 release. It may serve as a major signaling pathway for thrombin induced other events in HDFs, such as IL-8 release from HDFs[13] and proliferation of astrocytes [20].

\section{Conclusion}

Thrombin is a potent stimulus of proMMP-9 release from HDFs. The action of thrombin on HDFs is most likely through activation of PAR-1. JAK/STAT3 signaling pathway is involved in proMMP-9 release from HDFs. Since MMP-9 presents at elevated levels during early wound healing [21] the finding in the present study may suggest that thrombin is actively involved in tissue remodeling process of new wound in skin.

\section{Methods \\ Materials}

Cell culture medium RPMI 1640 and fetal bovine serum (FBS) were obtained from GIBCO BRL (Lifetechnologies, Rockville, MD, USA). PD98059, AG490, LY294002, phospho-p44/42 MAPK antibody, unphospho-p44/42 MAPK antibody, phospho-Akt antibody, unphospho-Akt antibody, phospho-STAT3 antibody and unphospho-STAT3 antibody were purchased from Cell Signaling Technology (Beverly, MA, USA). Human thrombin (T6884), biotin conjugated goat anti-rabbit immunoglobulins, biotin conjugated goat anti-mouse immunoglobulins, extr-Avidin-peroxidase, mouse anti-human $\beta$-actin and antibiotics (a mixture of penicillin and streptomycin) were from Sigma (St. Louis, MO, USA). Recombinant hirudin (catalog number 377950) was from Calbiochem (San Diego, CA, USA). PAR-1 agonist peptide (SFLLR-NH $\mathrm{NH}_{2}$ ) and its reverse peptide ( $\mathrm{RLLFS}-\mathrm{NH}_{2}$ ) were synthesized at the Xian Meiliang Co. (Xian, China). Mouse anti-human PAR-1, mouse anti-human PAR-2, anti-PAR-3 rabbit polyclonal antibody, anti-PAR-4 rabbit polyclonal antibody, goat anti-mouse IgG-cy3, goat anti-mouse IgG-FITC, goat antirabbit IgG-FITC, mouse IgG, rabbit IgG and PAR-1 blocking antibody (ATAP2, against amino acids 42-55 of thrombin receptor of human origin) were from Santa Cruz Biotechnology (Santa Cruz, CA, USA). Sybr green was from Cambrex Bio Science (Baltimore, USA). Most of the other reagents such as salt and buffer components were analytical grade and obtained from Sigma (St. Louis, MO, USA).

\section{Cell culture}

Samples of foreskins were obtained from four healthy donors (aged 18, 18, 20, 21 years, respectively) undergoing circumcision in the First Affiliated Hospital, Shantou University Medical College. The study adhered to the ten- 
ets of the Declaration of Helsinki, and all subjects signed an informed consent form before undergoing circumcision. HDFs were isolated by sequential enzymatic digestions and cultured in RPMI 1640 medium supplemented with $10 \%$ (vol/vol) FBS, 100 units/ml penicillin, and 100 $\mu \mathrm{g} / \mathrm{ml}$ of streptomycin at $37^{\circ} \mathrm{C}$ in an atomosphere of $5 \%$ $\mathrm{CO}_{2}$ until confluent islands of cells were observed. Since cells displayed the typical properties of spindle-shaped fibroblasts after the third passage, only passages 3 to 6 HDFs were used for the study. The purity of HDFs was at least $99 \%$ as assessed by detecting fibroblast marker using immunostaining with a monoclonal mouse anti-human fibroblast antibody (Dako, Glostrup, Denmark).

\section{Detection of PARs in HDFs by immunofluorescence staining}

Confluent fibroblasts were treated with nonenzymatic cell dissociation fluid to obtain single-cell suspensions. After being seeded onto eight-well chamber slides (Lab-Tek Permanox, Nunc, Life Technologies) at a density of $1 \times 10^{4}$ cells/well in $300 \mu \mathrm{l}$ of RPMI 1640 containing 10\% FBS, HDFs were incubated in a humidified atmosphere of air containing $5 \% \mathrm{CO}_{2}$ for $48 \mathrm{~h}$ at $37^{\circ} \mathrm{C}$, and then fixed with $4 \%$ paraformaldehyde for $3 \mathrm{~min}$ at room temperature. The fixed cells were incubated with mouse anti-human PAR-1, mouse anti-human PAR-2, rabbit anti-human PAR-3, or rabbit anti-human PAR-4 antibody, respectively for $16 \mathrm{~h}$ at $4^{\circ} \mathrm{C}$. This was followed by addition of the secondary antibodies including goat anti-mouse IgG-cy3 (for PAR-1), goat anti-mouse-FITC (for PAR-2) or goat antirabbit IgG-FITC (for PAR-3 and PAR-4) for 60 mins at room temperature. Mouse IgG or rabbit serum $(20 \mathrm{ng} / \mathrm{ml})$ was used as negative controls. After three washes with PBS, the chambers were removed, and coverslips were mounted with an antifade glycerol-PBS-based mountant (Dako, Glostrup, Denmark). The cells were visualized by using a confocal microscope (D-ECLIPSE C1, Nikon).

\section{Challenge of HDFs with thrombin and SFLLR-NH}

The cells were plated in 24-well tissue culture plates $(5 \times$ $10^{4} /$ well) and serum starved with serum-free medium overnight. After washing, the fresh medium with various concentrations of thrombin $(0.1,1,5 \mathrm{U} / \mathrm{ml}, \mathrm{U}=\mathrm{NIH}$ unit, $1 \mathrm{U} / \mathrm{ml}=6.7 \mathrm{nM})$, SFLLR-NH $\mathrm{NH}_{2}(1,10,100 \mu \mathrm{M})$, hirudin $(1,5 \mathrm{U} / \mathrm{ml})$ or thrombin with hirudin was added into each well for $6 \mathrm{~h}$. TGF $\beta$ at $10 \mathrm{ng} / \mathrm{ml}$ was used as a positive control. The culture supernatant was then collected and stored at $-80^{\circ} \mathrm{C}$ for subsequent analysis.

\section{RT-PCR analysis of expression of PARs and MMP-9 genes in HDFs}

After being exposed to various stimuli for $6 \mathrm{~h}$, the total RNA of HDFs was extracted by using an RNeasy Mini Kit (Qiagen, Germany). cDNA was synthesized from $2 \mu \mathrm{g}$ of RNA by using ProtoScript First Strand cDNA Synthesis Kit (Biolabs, New England, USA) according to the manufacturer's instructions. The cDNA was amplified using forward and reverse specific primers for amplifying human PARs. $\beta$-actin was used as an internal control. Primers were designed based on PAR sequences in Genbank using Omiga software and prepared by BioAsia Co.. The primer sequences were summarized in Table 1 . Cycling conditions were as follows: PAR-1, PAR-2, PAR-3, PAR-4, 30 cycles at $94^{\circ} \mathrm{C}$ for $1 \mathrm{~min}, 60^{\circ} \mathrm{C}$ for $1 \mathrm{~min}$, and $72^{\circ} \mathrm{C}$ for $1.5 \mathrm{~min}$; $\beta$-actin was amplified for 30 cycles at $94^{\circ} \mathrm{C}$ for 1 $\min , 55^{\circ} \mathrm{C}$ for $1 \mathrm{~min}$ and $72^{\circ} \mathrm{C}$ for $1 \mathrm{~min}$. The reaction for MMP-9 was allowed to proceed for 30 cycles at $94^{\circ} \mathrm{C}$ for $30 \mathrm{~s}, 57^{\circ} \mathrm{C}$ for $45 \mathrm{~s}$, and $72^{\circ} \mathrm{C}$ for $45 \mathrm{~s}$. The quality of the PCR product was analyzed on a $1.5 \%$ agarose gel, visualized with Sybr green and photographed under UV light. The results were expressed as the ratio of mRNAs of PARs or MMP-9 to $\beta$-actin after determination of the density of the bands on agarose gel by densitometer.

\section{Detection of proMMP-2 and proMMP-9 activities by gelatin zymography}

Metalloproteinases generated in culture supernatants were determined using gelatin zymography. Commercial available gelatinases A and B ( $2 \mu \mathrm{g}$; USbiological, New Orleans, LA, USA) were used as standards. Samples or standards were added to platelet-monocyte conditioned medium. The mixture was then placed in $2 \times$ non-reduc-

Table I: Primer sequences for PARs and MMP-9

\begin{tabular}{|c|c|c|c|}
\hline Primer & & Sequence & Size of product (bp) \\
\hline \multirow[t]{2}{*}{ PAR-I } & sense & 5'-CAGCTCCTGGCTGACACTCTTTGTC-3' & 500 \\
\hline & antisense & 5'-CGAGCAGGGTTTCATTGAGCACAT-3' & \\
\hline \multirow[t]{2}{*}{ PAR-2 } & sense & 5'-GTGGATGAGTTTCTGCATCTGTCCTCA-3' & 328 \\
\hline & antisense & 5'-CTGAGGCAGGTCATGGTCATGAAGAGAATGC-3' & \\
\hline \multirow[t]{2}{*}{ PAR-3 } & sense & 5'-GGCTGGACAGGAGCCACGAT-3' & 403 \\
\hline & antisense & 5'-AGCGGTTGATGCTGATGCAGG-3' & \\
\hline \multirow[t]{2}{*}{ PAR-4 } & sense & 5'-GGATCGCCTACCACCTGCGTG-3' & 401 \\
\hline & antisense & 5'-CCCGTAGCACAGCAGCATGG-3' & \\
\hline \multirow[t]{2}{*}{$\beta$-actin } & sense & 5'-AGGGGCCGGACTCGTCATACT-3' & 202 \\
\hline & antisense & 5'-GGCGGCAACACCATGTACCCT-3' & \\
\hline \multirow[t]{2}{*}{ MMP-9 } & sense & 5'-CGCCGCTCACCTTCAC-3' & 185 \\
\hline & antisense & 5'-GCCCAGGGACCACAACT-3' & \\
\hline
\end{tabular}


ing SDS sample buffer and electrophoresed in a 10\% polyacrylamide gel containing $0.1 \%$ gelatin. Following rinsing in $2.5 \%$ Triton $\mathrm{X}-100$ for $1 \mathrm{~h}$ and in distilled $\mathrm{H}_{2} \mathrm{O}$ for $2 \mathrm{~h}$ at room temperature the gel was subsequently incubated at $37^{\circ} \mathrm{C}$ for $24 \mathrm{~h}$ in the substrate buffer containing 50 $\mathrm{mmol} / \mathrm{L}$ Tris-base $(\mathrm{pH} 7.6)$ and $5 \mathrm{mmol} / \mathrm{L} \mathrm{CaCl}_{2}$. After staining with Coomassie Blue and destaining, the presence of gelatinases in the gel was identified as clear bands on a uniform blue and was quantified by densitometry. The density units were integrated optic density, which was area timed optical density. The ScionImage program was used to quantify the band. Identification of each type of gelatinase on the gel is based on the bands produced by the gelatinase standards.

\section{Western blot analysis of signal transduction pathways in HDFs upon thrombin stimulation}

To determine the optimal concentrations of the inhibitors of signal transduction pathways in HDFs, 25 and $50 \mu \mathrm{M}$ of PD98059, 20 and $40 \mu \mathrm{M}$ of LY294002, and 20 and 40 $\mu \mathrm{M}$ of AG490 were preincubated with HDFs for $30 \mathrm{~min}$ utes prior to adding $5 \mathrm{U} / \mathrm{ml}$ thrombin. Since $50 \mu \mathrm{M}$ of PD98059, $40 \mu \mathrm{M}$ of LY294002 and $40 \mu \mathrm{M}$ of AG490 almost completely abolished thrombin-induced phosphorylation of ERK1/2, Akt and STAT3 respectively (data not shown), whereas $25 \mu \mathrm{M}$ of PD98059, $20 \mathrm{M}$ of LY294002 and $20 \mu \mathrm{M}$ of AG490 inhibited thrombininduced phosphorylation of ERK1/2, Akt and STAT3 by approximately only $30 \%, 27 \%$ and $40 \%$ respectively, the higher concentration of each inhibitor was chosen as the optimal concentration throughout the study.

HDFs, which were planted in 12-well tissue culture plates, $1 \times 10^{6}$ per well, were serum starved overnight and then treated with $50 \mu \mathrm{M}$ of PD98059, $40 \mu \mathrm{M}$ of LY294002 or $40 \mu \mathrm{M}$ of AG490 for $30 \mathrm{~min}$ prior to addition of $5 \mathrm{U} / \mathrm{ml}$ thrombin. We examined the levels of downstream products of the following pathways: phospho-ERK1/2 in MAPK/ERK pathway, phospho-Akt in the PI3K/Akt pathway, and phospho-STAT3 in the JAK/STAT3 pathway. The levels of these products were determined at $30 \mathrm{~min}$ (for phospho-STAT3 only), $2 \mathrm{~h}$ and $6 \mathrm{~h}$ time points. The levels of proMMP-2 and proMMP-9 in the supernatants were determined by zymography.

The cells were lysed in phosphorylation lysis buffer (0.5\%Triton X-100, $150 \mathrm{mM} \mathrm{NaCl,} 200 \mu \mathrm{M}$ sodium orthovanadate, $10 \mathrm{mM}$ sodium pyrophosphate, $100 \mathrm{mM}$ sodium fluoride, $1 \mathrm{mM}$ EDTA, $50 \mathrm{mM}$ Hepes, $1.5 \mathrm{mM}$ magnesium chloride, $10 \%$ glycerol, $1 \mathrm{mM}$ phenylmethylsulfonyl fluoride, and $10 \mu \mathrm{g} / \mathrm{ml}$ aprotinin) for $60 \mathrm{~min}$ at $4{ }^{\circ} \mathrm{C}$. After removing cell debris by centrifugation at $10,000 \mathrm{~g}$ for $30 \mathrm{~min}$, the supernatants were collected. Equal amount of the cell extracts were loaded on $10 \%$ polyacrylamide gel for electrophoresis. Proteins in the gel were then transferred onto polyvinylidene difluoride (PVDF) membranes (Millipore Corporation, Billerica, MA). Following blocking the membranes with 5\% skim milk in TBST (50 mM Tris, $0.15 \mathrm{M} \mathrm{NaCl}, 0.1 \%$ Tween 20 , $\mathrm{pH}$ 7.6) for $1 \mathrm{~h}$ at room temperature, the primary antibody was added. Biotinylated goat anti-rabbit immunoglobulins or biotinylated goat anti-mouse immunoglobulins were used as secondary antibodies, which was followed by addition of extr-Avidin-peroxidase. The protein bands were detected by a chemiluminescence method according to manufacturer's instructions (supersignal West Pico, Pierce). Radiographs were photographed with a digital scanning system. The same membranes were stripped at $55^{\circ} \mathrm{C}$ for $30 \mathrm{~min}$ in stripped buffer containing $0.7 \% \beta$-mercaptoethanol, $2 \%$ SDS, and 62.5 $\mathrm{mM}$ Tris ( $\mathrm{pH} 6.8$ ) prior to being stained with mouse antihuman $\beta$-actin monoclonal antibody as described above.

Densitometry analysis of immunoblots was carried out using ScionImage software. The relative levels of phospho-ERK1/2, Akt, and STAT3 were expressed as the ratio to $\beta$-actin.

\section{Statistical analysis}

All data were expressed as mean \pm SD. Each experiment was repeated four times. Statistical analysis was performed using one-way ANOVA or Students's $t$ test with SPSS (version 12.0). $P$ value less than 0.05 was considered as statistically significant.

\section{Abbreviations}

Matrix metalloprotease (MMP); Protease-activated receptors (PAR); human dermal fibroblast (HDF); mitogenactivated protein kinase (MAPK); extracellular signal-regulated kinase (ERK); Janus kinase(JAK); signal transducer and activators of transcription (STAT); phosphotidylinositol 3-kinase (PI3K); reverse transcription-polymerase chain reaction (RT-PCR)

\section{Authors' contributions}

LW conceived of and executed the experiments in this study, and drafted the manuscript. JL provided advice with design of experiments and participated in the Westen bolt experiments. SH supervised the study and extensively corrected the manuscript. All authors read and approved the final manuscript.

\section{Acknowledgements}

This project was supported by the grants from the Li Ka Shing Foundation, Hong Kong, China (No. C020000I); the National Natural Science Foundation of China (No. 3047 I60I, 305708 I3); the Planned Science and Technology Project of Guang Dong Province, China (No. 2003B3 I502) and the Natural Science Foundation of Guang Dong Province, China (No. 04106122 ). 


\section{References}

I. Nagase H, Woessner JF Jr: Matrix Metalloproteinases. J Biol Chem 1999, 274:2|49|-2|494.

2. Pucci-Minafra I, Minafra S, Rocca LG, Barranca M, Fontana S, Alaimo G, Okada Y: Zymographic analysis of circulating and tissue forms of colon carcinoma gelatinase A (MMP-2) and B (MMP-9) separated by mono- and two-dimensional electrophoresis. Matrix Biology 200I, 20:4I 9-427.

3. Akagi A, Tajima S, Ishibashi A, Yamaguchi N, Nagai Y: Expression of type XVI collagen in human skin fibroblasts: enhanced expression in fibrotic skin diseases. J Invest Dermatol 1999, I I 3:246-250.

4. Chi L, Li Y, Stehno-Bittel L, Gao J, Morrison DC, Stechschulte DJ, Dileepan KN: Interleukin-6 production by endothelial cells via stimulation of protease-activated receptors is amplified by endotoxin and tumor necrosis factor-alpha. I Interferon Cytokine Res 200I, 21:23I-240.

5. Chambers RC, Leoni P, Blanc-Brude OP, Wembridge DE, Laurent GJ: Thrombin is a potent inducer of connective tissue growth factor production via proteolytic activation of protease-activated receptor-I. J Biol Chem 2000, 275:35584-3559I.

6. Weiss RH, Nuccitelli R: Inhibition of tyrosine phosphorylation prevents thrombin-induced mitogenesis, but not intracellular free calcium release, in vascular smooth muscle cells. J Biol Chem 1992, 267:5608-56/3.

7. Mari B, Guerin S, Far DF, Breitmayer JP, Belhacene N, Peyron JF, Auberger $\mathrm{P}$ : Thrombin and trypsin-induced $\mathrm{Ca}^{2+}$ mobilization in human $\mathrm{T}$ cell lines through interaction with different protease-activated receptors. FASEB J 1996, 10:309-316.

8. Bolton SJ, McNulty CA, Thomas RJ, Hewitt CR, Wardlaw AJ: Expression of and functional responses to protease-activated receptors on human eosinophils. J Leukoc Biol 2003, 74:60-68.

9. Colognato R, Slupsky JP, Jendrach M, Burysek L, Syrovets T, Simmet $\mathrm{T}$ : Differential expression and regulation of protease-activated receptors in human peripheral monocytes and monocyte-derived antigen-presenting cells. Blood 2003, 102:2645-2652.

10. Coughling SR: How the protease thrombin talks to cells. Proc Natl Acad Sci U S A 1999, 96: I 10230-I I 0237.

II. Vu TK, Hung DT, Wheaton VI, Coughlin SR: Molecular cloning of a functional thrombin receptor reveals a novel proteolytic mechanism of receptor activation. Cell 1991, 64:1057-1068.

12. Cottrell GS, Coelho AM, Bunnett NW: Protease-activated receptors: the role of cell-surface proteolysis in signalling. Essays Biochem 2002, 38:169-183.

13. Wang L, Luo JM, He SH: Induction of interleukin-8 secretion and activation of ERKI/2, p38 MAPK signaling pathways by thrombin in dermal fibroblast. Int J Biochem Cell Biol 2006, 38: $157 \mid-1583$

14. Garbuzenko E, Berkman N, Puxeddu I, Kramer M, Nagler A, LeviSchaffer $F$ : Mast cells induce activation of human lung fibroblasts in vitro. Exp Lung Res 2004, 30:705-72I.

15. Kahn ML, Zheng YW, Huang W, Bigornia V, Zeng D, Moff S, Farese RV Jr, Tam C, Coughlin SR: A dual thrombin receptor system for platelet activation. Nature 1998, 394:690-694.

16. Domotor E, Benzakour O, Griffin JH, Yule D, Fukudome K, Zlokovic BV: Activated protein $C$ alters cytosolic calcium flux in human brain endothelium via binding to endothelial protein $C$ receptor and activation of protease activated receptor-I. Blood 2003, I01:4797-4801.

17. Bachili EB, Pech CM, Johnson KM, Johnson DJ, Tuddenham EG, $\mathrm{McVey} J \mathrm{H}$ : Factor $\mathbf{X a}$ and thrombin, but not factor VIla, elicit specific cellular responses in dermal fibroblast. J Thromb Haemost 2003, I: I 935-1944.

18. Hou L, Ravenall S, Macey MG, Harriott P, Kapas S, Howells GL: Protease-activated receptors and their role in IL-6 and NF-IL-6 expression in human gingival fibroblasts. J Periodontal Res 1998, 33:205-2II.

19. Dronadula N, Liu Z, Wang C, Cao H, Rao GN: STAT-3-dependent cytosolic phospholipase A2 expression is required for thrombin-induced vascular smooth muscle cell motility. J Biol Chem 2005, 280:3।I2-3I20.

20. Wang H, Ubl JJ, Stricker R, Reiser G: Thrombin (PAR-I)-induced proliferation in astrocytes via MAPK involves multiple signaling pathways. Am J Physiol cell Physiol 2002, 283:CI35I-CI364.
21. Gillard JA, Reed MW, Buttle D, Gross SS, Brown NJ: Matrix metalloproteinase activity and immunohistochemical profile of matrix metalloproteinase- 2 and -9 and tissue inhibitor of metalloproteinase-I during human dermal wound healing. Wound Repair Regen 2004, 1 2:295-304.
Publish with Bio Med Central and every scientist can read your work free of charge

"BioMed Central will be the most significant development for disseminating the results of biomedical research in our lifetime. "

Sir Paul Nurse, Cancer Research UK

Your research papers will be:

- available free of charge to the entire biomedical community

- peer reviewed and published immediately upon acceptance

- cited in PubMed and archived on PubMed Central

- yours - you keep the copyright

Submit your manuscript here:

http://www.biomedcentral.com/info/publishing_adv.asp 